Галаган В. І., канд. військ. наук, доцент

(0000-0001-9578-0895)

Центр воєнно-стратегічних досліджень Національного університету оборони України імені Івана Черняховського, Київ

\title{
Пропозиції щодо розроблення та впровадження аналітичного модуля контролю за процесом закупівель товарів, робіт та послуг для потреб Збройних Сил України
}

Резюме. У статті на основі детального аналізу функціонування системи електронних торгів надано пропозиції щодо розроблення та впровадження аналітичного модуля контролю за процесом закупівель товарів, робіт та послуг для потреб Збройних Сил України.

Ключові слова: система електронних торгів; аналітичний модуль контролю; аналітична система.

Постановка проблеми. Відповідно до положень Стратегічного оборонного бюлетеня України [1] очікуваним результатом $\epsilon$ створення за принципами та стандартами, прийнятими в державах-членах НАТО, ефективних, мобільних, оснащених сучасним озброєнням, військовою та спеціальною технікою сил оборони зразка 2020 року, здатних гарантовано забезпечити оборону держави та адекватно і гнучко реагувати на воєнні загрози національній безпеці України, а проте раціонально використовувати наявний потенціал (спроможності) та ресурси держави.

Для виконання поставлених завдань у Збройних Силах (3С) України на сьогодні проводиться оборонна реформа, під час якої здійснюється перехід на нову відкриту, позбавлену корупційної складової систему оборонних закупівель.

Крім того, проведення ЗС України Операції об'єднаних сил та залучення для цього великої кількості з'єднань, частин і підрозділів значно підвищують потреби в логістичному забезпеченні, яке досить суттєво залежить від процесу закупівель товарів, робіт і послуг.

Для контролю за закупівлями товарів, робіт i послуг у державному масштабі створена та використовується система електронних торгів ProZorro. Після початку роботи системи електронних торгів ProZorro Міністерство оборони України активно включилося в роботу та стало одним із лідерів за кількістю укладених угод серед інших учасників, що призвело до значної економії бюджетних коштів.

Суттєве спрощення процедур призвело до залучення до роботи в системі електронних торгів тільки визначених окремих категорій посадових осіб (фахівців) Міністерства оборони України, переважно Департаменту державних закупівель та постачання матеріальних ресурсів Міністерства оборони України, які готують документацію та контролюють проходження тендерних процедур.

Водночас більша частина зацікавлених безпосередніх замовників товарів, робіт, послуг не має доступу до детальної інформації щодо тендерного процесу, що часто призводить до вибору учасників торгів, які не стануть добросовісними постачальниками та партнерами, не виконуватимуть належним чином узяті зобов'язання (як правило, це терміни поставок, виконання робіт i їх якість). На часті випадки невиконання своїх зобов’язань постачальниками неодноразово зверталася увага і керівництва Міністерства оборони України [2].

Отже, проблема забезпечення всіх зацікавлених осіб (до ланки начальника служби частини, 3'єднання) необхідною аналітичною інформацією щодо процесу закупівель товарів, робіт, послуг є досить актуальною задачею. Тим більше, що саме вказані категорії $\epsilon$ найбільш обізнаними 3 діяльністю, спроможностями та порядністю місцевих (гарнізонних) постачальників.

Аналіз останніх досліджень та публікацій. На сьогодні більшість фахових публікацій [3-5] 3 питань розроблення та впровадження інформаційно-аналітичних систем стосуються бізнес-сектору, не враховуючи специфіку діяльності державних структур, зокрема, i Міністерства оборони України.

Досвід роботи та проведений аналіз показав, що нині питанням забезпечення інформацією щодо процесу закупівель товарів, робіт і послуг у Міністерстві оборони України приділяється недостатня увага.

У межах створення та функціонування 
єдиної інформаційної системи управління оборонними ресурсами (DRMIS), яка включатиме інформаційні системи (управління інфраструктурою, особовим складом, видами забезпечення та ін.) планується циркуляція значної кількості даних, які також мають ураховувати i майбутні закупівлі товарів, робіт і послуг для забезпечення потреб ЗС України. Водночас обмін даними між інформаційною системою DRMIS та системою електронних торгів ProZorro поки не планується.

Указаний стан потребує розроблення власного аналітичного інструментарію, доступного для всіх категорій посадових осіб (фахівців), які мають відношення до процесу закупівель у ЗС України та дасть змогу контролювати його хід (аналізувати, проводити моніторинг закупівель та їх учасників). Отримана деталізована інформація може використовуватися керівним складом ЗС України для подальшого прийняття обгрунтованих рішень щодо забезпечення потреб військ (сил).

Це завдання особливо актуалізується на етапі проведення заходів трансформації системи об'єднаного керівництва силами оборони та військового управління в $3 \mathrm{C}$ України під час реорганізації підрозділів Генерального штабу ЗС України та перерозподілу функцій між ними.

3 огляду на викладене, метою статті $\epsilon$ проведення детального аналізу, обгрунтування та надання відповідних пропозицій щодо розроблення власного аналітичного модуля контролю за процесом закупівель товарів, робіт i послуг для потреб Збройних Сил України.

Виклад основного матеріалу. Система електронних торгів стала невід'ємною частиною українських державних закупівель, зокрема i для забезпечення потреб ЗС України.

У державному масштабі закупівля товарів, робіт і послуг здійснюється через електронну систему ProZorro, правовий статус якої закріплений у Законі України "Про публічні закупівлі" від 25.12.2015 № 922-VIII, де була запроваджена обов'язковість проведення публічних електронних процедур закупівель для головних розпорядників коштів і монополістів [6].

Загалом система ProZorro - це база даних, що знаходиться на окремому сервері та доступ до якої здійснюється тільки через електронні майданчики, які мають доступ до системи, наприклад, Української
Універсальної Біржі (на сьогодні використовуеться 19 електронних майданчиків). Завдяки такій організації процесу закупівель, держава не зможе втручатися у торги, лобіювати або відсіювати учасників, чи впливати на них.

Сутність роботи ProZorro полягає у проведенні зворотного аукціону, у якому учасники змагаються за право постачати замовнику певний товар чи послугу. Під час проведеного аукціону переможе той, у кого ціна виявиться найнижчою, а технічні характеристики товару або послуги відповідають тим, що заявлені замовником у тендерній документації.

Отже, 32016 року основна частина публічних закупівель здійснюється за допомогою електронних торгів. Конкурентний діалог застосовується у випадках, коли замовнику важко визначитись зі специфікацією та технічними характеристиками запланованих робіт або коли закуповуються інформаційні послуги та наукові дослідження. Переговорна процедура $\epsilon$ винятком і застосовується здебільшого для проведення архітектурних конкурсів і закупівлі творів мистецтва.

Після запуску системи ProZorro та отримання великої кількості відкритих даних в Україні виникла необхідність проведення їх упорядкування та аналізу, що призвело до появи багатьох інструментів і сервісів, які допомагають аналізувати, проводити моніторинг закупівлі та їх учасників.

На сьогодні існують аналітичні інструменти для контролю та моніторингу публічних закупівель як від команди розробників системи ProZorro, так і від сторонніх команд. На жаль, ЗС України не мають власних i не використовують аналітичних засобів інших розробників.

Найбільш розвиненим і досконалим $\epsilon$ моніторинговий портал DoZorro - платформа, де кожен учасник системи (постачальник, замовник, контролюючий орган, громадянин) може дати зворотній зв'язок державному замовнику чи постачальнику, обговорити та оцінити умови конкретної закупівлі, провести аналіз закупівлі окремого державного органу чи установи, підготувати та подати офіційне звернення до контролюючих органів та ін.

\section{Розроблення} індивідуальних аналітичних програм пояснюється тим, що у кожного учасника публічних закупівель існують певні пріоритети, i, відповідно, свої потреби в аналізі інформації, але спільним, для кожного учасника, $\epsilon$ ефективне 
використання коштів i мінімізація ризиків пов'язаних 3 недобросовісними постачальниками товарів i послуг та стороннім втручанням будь-яких зацікавлених осіб.

Негативний приклад був і в діяльності 3С України, а саме будівництво табірного містечка на території військового полігону “Широкий лан”. Забудовником, згідно 3 умовами договору, об'єкт мав бути готовим i зданим в експлуатацію в 2018 році, проте донині частина будівельних робіт досі не виконана. Цей факт указує на недостатню інформованість керівного складу (фахівців), які приймали відповідні рішення, щодо можливостей і порядності забудовника [7].

Команда розробників електронної системи ProZorro пропонує за аналітичний інструмент використовувати в моніторинговому порталі DoZorro два основних модулі "Публічний модуль аналітики" та "Професійний модуль аналітики”. Кожен 3 модулів має свою визначену направленість на користувача.

“Публічний модуль аналітики” дає змогу замовникам знайти типову документацію, перевірити постачальників i додатково оцінити рівень власної ефективності. Цей модуль у режимі онлайн відображає усі закупівлі, що проводяться через електронну систему ProZorro, має широкий функціонал (від загальної інформації про стан системи до викриття порушень і змов).

“Публічний модуль аналітики" має великий перелік критеріїв, за якими можна фільтрувати та сортувати закупівлі, плани, постачальників i замовників, щоб отримати потрібну інформацію. Модуль аналітики нараховує близько 450 полів відборів, які користувач може застосувати під час детального аналізу. Усі поля відборів поділені на групи, які структурують їх і поєднують за функціональними особливостями. За допомогою цієї інформації $\epsilon$ можливість оцінити стан ринку та своє положення на ньому, оцінити позиції конкурентів та поведінку партнерів, а також знайти кращі практики із закупівель.

Відмінність "Публічного модуля аналітики" від "Професійного модуля аналітики" полягає в можливості останнього створювати власні напрями аналізу, загалом “Професійного модуля аналітики".

"Професійний модуль аналітики" забезпечує розгорнутий аналіз закупівлі через систему ProZorro завдяки понад 1000 різноманітним показникам. Крім того, модуль дає змогу налаштувати під свої потреби таблиці та графіки об'єктів, або навіть створити власні показники.

Загалом, моніторинговий портал DoZorro - це платформа, де кожен учасник системи (постачальник, замовник, контролюючий орган, громадянин) може дати зворотній зв'язок державному замовнику чи постачальнику, обговорити та оцінити умови конкретної закупівлі, проаналізувати закупівлі окремого державного органу чи установи, підготувати та подати офіційне звернення до контролюючих органів та багато іншого. Крім того, портал дає змогу обговорити конкретний тендер iз потенційними та наявними постачальниками, дізнатись їхню експертну думку про правильність формулювань у тендерній документації, отримати професійну експертизу тощо. Державні замовники можуть не лише дати оцінку конкретному постачальнику, але й проаналізувати зворотній зв'язок від бізнесу та внести відповідні зміни до закупівельного процесу i створити власну систему ризик-менеджменту [8].

Обидва модулі створені за допомогою програмного забезпечення Qlik, основною технологічною особливість якого є реалізація асоціативної архітектури, технології обробки даних в оперативній пам'яті (в пам'яті), інтуїтивно зрозумілого користувальницького інтерфейсу, сумісного 3 новими технологіями даних.

У системі Qlik реалізована унікальна запатентована технологія резидентного (inmemory, тобто в оперативній пам'яті) асоційованого аналізу, яка створила фундамент для створення BI (Business intelligence) - платформи нового покоління Qlik. BI-технологія Qlik - сучасна розпорядча аналітична система 3 наданням завдань на виконання, яка складається 3 комбінацій "традиційної” або дескриптивної аналітики (відповідає на запитання “що?”), діагностичної аналітики (“чому?”), прогнозної аналітики (“що станеться?”).

Кожний 3 модулів аналітики, який розглядається, побудований на різних функціональних рішеннях Qlik - Qlik View ("Професійний модуль аналітики") та Qlik Sense ("Публічний модуль аналітики"), які виконані на одній програмній платформі.

Насамперед, слід зазначити, що QlikView i Qlik Sense - аналітичні інструменти з єдиною логікою i на єдиній платформі. Ключова відмінність у позиціонуванні: QlikView подається як корпоративна платформа, а 
Qlik Sense - iнструмент персонального дослідження даних кінцевим користувачем.

Qlik View - програмне забезпечення, яке дає змогу користувачам будь-якого рівня, від новачків до фахівців, отримувати i співставляти дані з будь-якого джерела: баз даних, аналогічних SQL Server або Oracle, а також файлів Excel, XML або текстових файлів. Додатки для підприємств, наприклад, $S A P$ (ERP-система для планування ресурсів підприємств), можуть бути також використані в якості джерела даних для виконання аналізу QlikView.

Qlik Sense - додаток для самостійної візуалізації, дослідження і моніторингу даних, який має інтуїтивно зрозумілий інтерфейс, що дає змогу користувачам не мати спеціальних знань 3 обробки даних та полегшує створення нових діаграм без написання кодів і формул. Має можливість обробки даних безпосередньо в оперативній пам'яті та дає змогу оперувати великими обсягами інформації. Qlik Sense належить до класу аналітичних систем самообслуговування Self-Service BI.

Аналітична система Qlik може використовувати методи штучного інтелекту для оперативного прогнозування. Отже, значною перевагою цього програмного забезпечення $є$ можливість виконувати роботу на будь-яких пристроях (ноутбук, планшет, телефон, комп'ютер), що $є$ досить вагомим фактором для ЗС України. Система автоматично масштабується під розмір екрану, має змогу роботи з даними Offline (без доступу до мережі), сумісної роботи 3 декількома вікнами та майже необмежені можливості візуалізації аналітичних даних.

Утім, згадані модулі аналітики мають певні особливості, які впливають на можливість їх повноцінного впровадження та застосування в діяльності 3С України. Насамперед, незначна кількість безкоштовних ліцензій та обмежений термін безкоштовної ліцензії на користування (1 місяць), у разі покупки комерційної ліцензіі значна іiі вартість (1350 \$ - одна ліцензія).

Отже, $з$ огляду на наведене, можна дійти висновків:

в Україні розроблена та ефективно використовується в інтересах державного сектору система публічних закупівель ProZorro, яка здійснюється за допомогою електронних торгів;

для контролю та моніторингу публічних закупівель у системі ProZorro є можливість використовувати аналітичні інструменти (моніторинговий портал DoZorro); цінова політика та політика доступу розробника програмного забезпечення DoZorro до використання аналітичних модулів обмежує їх широке застосування для дієвого контролю за процесом закупівель товарів, робіт і послуг для потреб ЗС України;

керівний склад (фахівці), які готують i приймають управлінські рішення та контролюють процес закупівель товарів, робіт i послуг для потреб ЗС України мають тільки загальну інформацію із системи ProZorro (без необхідної деталізації);

для моніторингу та контролю закупівель для потреб ЗС України керівному складу (фахівцям) Міністерства оборони та Генерального штабу 3С України потрібен власний аналітичний модуль, який дасть змогу відслідковувати будь-які фінансові дії щодо організацій (структур) та здійснювати прогноз на основі отриманих реальних статистичних даних.

Для впровадження пропозиції щодо розроблення власного аналітичного модуля для потреб ЗС України бажано використовувати програмні продукти, які розповсюджуються безкоштовно або були раніше закуплені для потреб Міністерства оборони України, що призведе надалі до значної економії бюджетних коштів.

На сьогодні закуплена та знаходиться у користуванні Міністерства оборони України сучасна аналітична платформа 3 асоціативною технологією аналізу QlikView. За допомогою програмного забезпечення QlikView вже було розроблено макет автоматизованого робочого місця керівного складу Міністерства оборони України за напрямом управління нерухомим військовим майном, який проходить етап тестування в структурах, що займаються інфраструктурним забезпеченням [9]. Тобто, для розроблення та налаштування власного аналітичного модуля $є$ підготовлені досвідчені спеціалісти та отриманий певний досвід 3 розроблення програмних продуктів на базі Qlik.

Крім того, для розроблення, налаштування та впровадження власного аналітичного модуля контролю за процесом закупівель товарів, робіт і послуг для потреб 3С України необхідно виконати певні заходи 3 організаційної та технічної підтримки, а саме:

розгортання на базі Головного управління зв'язку та інформаційних систем Генерального штабу 3С України серверного обладнання $з$ доступом до мережі “Інтернет”, забезпечення його працездатності та підтримки цілодобової роботи; 
організація та проведення консультаційної підтримки 3 розробником програмного забезпечення DoZorro (TOB “АрБіCi Груn”);

отримання у розробника програмного забезпечення DoZorro моделі аналітичної системи (у вигляді виконуваного файла) та розміщення його на серверному обладнанні Генерального штабу ЗС України;

налаштування та перевірка процесу обміну даними із системою ProZorro;

організація та налаштування доступу користувачів (за переліком ролей i повноважень);

налагодження процесу впровадження програмного продукту та супроводження роботи користувачів, подальший розвиток власної асоціативної систему аналізу.

Тобто, розроблення, впровадження та використання власного модуля $B I$-аналітики для структур (організацій) 3С України 3 доступом до системи ProZorro дає змогу одразу отримати необхідну інформацію, яка стосується безпосередньо Міністерства оборони України, мати на початковому екрані саме ті показники, які $є$ специфічними для посадової особи (фахівця) та проводити аналіз закупівель за особисто вибраними критеріями, або створити їх для себе i використовувати надалі.

Окрім того, наявність власного аналітичного модуля дає змогу поєднувати дані 3 різних джерел інформації як 3 Міністерства оборони України, так i iнших державних i недержавних відкритих i закритих реєстрів. Так, наприклад, поєднання даних щодо закупівель структурами (організаціями) 3С України (юридичним особами) 3 даними реєстру декларацій посадових осіб, фізичних осіб (i ïх близьких родичів), може значно знизити корупційні ризики під час проведення закупівель, або визначити ймовірність корупційної складової вже проведених тендерів.

Висновки. Отже, проведений аналіз показує, що розроблення та впровадження власного аналітичного інструментарію дасть змогу контролювати процес закупівель і надавати деталізовану інформацію керівному складу Міністерства оборони України та Генерального штабу 3С України для подальшого прийняття обгрунтованих рішень щодо забезпечення потреб військ (сил). До того ж, етап розроблення та впровадження аналітичного модуля контролю за процесом закупівель товарів, робіт і послуг може бути максимально спрощеним i фінансово незатратним завдяки отриманому раніше досвіду роботи з програмним забезпеченням i наявними ліцензіями на його використання.

Напрацювання, які будуть реалізовані у власному аналітичному модулі можуть бути успішно використані під час побудови DRMIS та під час створення робочого макету базового рівня інформаційної інфраструктури Міністерства оборони України.

Подальші дослідження за доцільно зосередити на питаннях розроблення та впровадження аналітичних модулів за видами матеріально-технічного забезпечення військ (сил).

\section{СПИСОК ВИКОРИСТАНОЇ ЛІТЕРАТУРИ}

1. Про рішення Ради національної безпеки і оборони України від 20 травня 2016 року “Про Стратегічний оборонний бюлетень України” : Указ Президента України від 06.06.2016 р. №240/2016. URL: http://www.president. gov.ua/news/prezident-zatverdivstrategichnij-oboronnij-byuleten-ukrayin-37309 (дата звернення: 15.04.2020).

2. Виступ Міністра оборони України від 10.01.2019. URL: https://ukurier.gov.ua/uk/articles/ministr-oboronistepan-poltorak-use-sho-zakupovuye/ (дата звернення: 15.04.2020).

3. Бородулин А. Разработка информационноаналитических систем корпоративного управления. Вестник Тверского государственного университета. Экономика и управление. 2016. № 2. C. $159-165$.

4. Белов В. Информационно-аналитические системы. Основы проектирования и применения : учебн.практ. пособ. изд. 2-е, перераб. и доп. Москва : МГУ экономики, статистики и информатики,2005. $111 \mathrm{c}$.

5. Бусол О. Перспективи використання інформаційноаналітичних систем. Тези доповіді на міжнародні конференції.

URL: http://conference.nbuv.gov.ua/report/view/id/335 (дата звернення: 15.04 .2020$)$

6. Про публічні закупівлі : Закон України від 25.12.2015 p. № 922-VIII. URL: https://ukurier.gov.ua/uk/articles/ministr-oboronistepan-poltorak-use-sho-zakupovuye/ (дата звернення: 15.04.2020).

7. Державне бюро розслідувань. ДБР розслідує розтрату 37 млн під час будівництва на полігоні “Широкий лан”. URL: https://dbr.gov.ua/news/dbrrozslidue-roztratu-37-mln-pid-chas-budivnictva-napoligoni-shirokiy-lan (дата звернення: 15.04.2020).

8. Аналітичні інструменти для контролю та моніторингу публічних закупівель. URL: https://dozorro.org/tools (дата звернення: 15.04.2020).

9. Галаган В., Бондарчук С., Полішко С. Формування загального обрису інформаційно-аналітичного автоматизованого робочого місця керівного складу управління нерухомим військовим майном $3 \mathrm{C}$ України. Оборонний вісник. 2018. №2. 


\section{Proposals for development and implementation of an analytical module for monitoring the process of procurement of goods and services for the needs of the Armed Forces of Ukraine}

\section{Annotation}

Since the time when ProZorro e-trading system has been created and used to control the procurement of goods, works and services on a national scale the Ministry of Defense of Ukraine became one of the leaders in the number of concluded agreements among other participants, and this is led to save significant amount of funds in budget resources.

Currently there is a problem of providing all interested persons (up to the level of the head of the service of the unit, connection) with the necessary analytical information about procurement process. These categories of servicepersons are more aware about the activities, capabilities and decency of local suppliers.

An analysis shows that the development and implementation of own analytical tools will control the procurement process and provide detailed information to the leadership of the Ministry of Defense of Ukraine and the General Staff of the Armed Forces of Ukraine for further decisions to meet the needs of units of the Armed Forces. The development and implementation of such analytical module can be simplified and financially inexpensive due to previous experience with software and existing licenses for its use.

The developments that will be implemented in our own analytical module can be successfully used even in the construction of a single information resource management system DRMIS (Defense Resources Management Information System) and the creation of a working layout of the basic level of information infrastructure of the Ministry of Defense of Ukraine.

Keywords: electronic bidding system; analytical control module; analytical system. 